\title{
A Study of Anthropometry Measurement of Shariya Tribe Lactating Women in Baran District of Rajasthan, India
}

\author{
Tanuja Bairwa*, Seema Jat, Kavita Bairwa and Devi Sahay Bairwa \\ Maharana Pratap University of Agriculture and Technology, Udaipur, Rajasthan, India \\ *Corresponding author
}

\begin{tabular}{|c|c|}
\hline & A B S T R A C T \\
\hline & \multirow{6}{*}{$\begin{array}{l}\text { The present study was conducted with an objective to assess Anthropometry measurement } \\
\text { of lactating women. The study was conducted at Kishanganj and Shahbad panchayat } \\
\text { samitie of Baran district of Rajasthan. One twenty participants range between } 18-45 \text { years } \\
\text { lactating women ( } 0-12 \text { months). The data was collected in Again } 60-60 \text { lactating women } \\
\text { from two panchayat samities Kishanganj and Shahbad was selected for imparting } \\
\text { nutritional education from the above } 120 \text { sample. The data obtained was analyzed using } \\
\text { frequency, mean and percentage. All respondents selected (lactating women } 0-12 \text { months) } \\
\text { were lying in the age group of } 18-45 \text { years. Among them } 70 \% \text { lactating women }(0-6 \\
\text { months) were in the age group of } 15-25 \text { year and in similar percentage of women }(23.33 \% \\
\text { and } 26.66 \%) \text { were in age of } 26-35 \text { year. The anthropometric indices like mean, height and } \\
\text { mean weight of lactating women was } 154.03 \mathrm{~cm}(0-6 \text { months), } 155.18 \mathrm{~cm} \text { height }(6-12 \\
\text { month) and } 49.36 \mathrm{~kg}(0-6 \text { month) and other } 52.08 \mathrm{~kg} \text { weight }(6-12 \text { month) of lactating } \\
\text { women respectively and Distribution of lactating women on the basis of BMI showed that } \\
\text { although } 66.66 \% \text { (0-6 month), } 61.66 \% \text { (6-12 month) respondents were in normal range but } \\
38.33 \% \text { were under weight. It can be concluded that the nutritional knowledge of the } \\
\text { participant was very low. Anthropometric measurements showed that majority of the } \\
\text { lactating women were underweight. }\end{array}$} \\
\hline Keywords & \\
\hline $\begin{array}{l}\text { Anthropometric } \\
\text { measurement, } \\
\text { Shariya tribe } \\
\text { lactating women. }\end{array}$ & \\
\hline Article Info & \\
\hline $\begin{array}{l}\text { Accepted: } \\
\text { 04 July } 2017 \\
\text { Available Online: } \\
\text { 10 September } 2017\end{array}$ & \\
\hline & \\
\hline
\end{tabular}

\section{Introduction}

About half of the World's total population of indigenous people, often referred as tribals, is living in India. The tribal population in Indian language known as "Adibasi", stands for original inhabitants, constitutes 8.1 per cent of the total Population of India. A general feature of the tribal population of the country is their exclusive geographical habitat. But there are certain communities among them, who live in more or less total isolation in a life style, which shows only a little change from that of centuries ago. The Shariya is one of those primitive tribes inhabiting 'Baran' district in the State of Rajasthan. The total population of Shariya is 79,312 with sex ratio of 951 females per 1000 males. A majority (93\%) of the Shariya population is inhabitants of Kishanganj and Shahbad blocks of Baran district. The health problems of any community are influenced by interplay of various factors including social, economic and political ones. The common beliefs, customs, practices related to health and disease in turn influence the health seeking behavior of the community. There is a consensus agreement that the health status of 
the tribal population is very poor and worst among the primitive tribes because of their isolation, remoteness and being largely unaffected by the developmental processes going on in the country. Food is a prerequisite not only for attaining good health but also for maintaining adequate growth and body equilibrium (Rao et al., 2006). The poor are caught in a vicious cycle of: poverty breeds ill-health, and ill-health keeps poor people poor (Wagstaff, 2000). Kapoor et al., (2009) studied the Shariya, a primitive tribe of central India, with an objective to assess the nutritional profile and associated socioeconomic factors. A cross sectional sample of 364 adult males and females aged 18-60 years was studied. Stature, body weight, skin fold thickness, circumferences, fat percent, grip strength and blood pressure were measured on each subject. Body mass index, Trunk extremity ratio and Grand mean thickness were computed statistically. A higher percentage of chronic energy deficient (CED) males and female subjects indicated a poor nutritional status of Shariya. A few over weight males were also found. More females were found to be undernourished than males as per the cut off values of MUAC.

All the subjects were found to have normal blood pressure with the exception of a few hypertensive cases among males in overweight category. An influence of changing life style among Shariya males was more noticeable. Bakhetia and Jain (2007) conducted a study on 100 lactating women. In their study height, weight, mid-upper arm circumference and skin fold thickness of the subjects were measured by standard methods and then compared with standards of ICMR (Indian Council of Medical Research) and NCHS (National Center for Health Statistics). Study reported that height and weight of the subjects were higher than the ICMR standard and weight, mid - upper arm circumference and skin fold thickness were lower than the
NCHS standard. A positive co-relation between distance covered with height $(\mathrm{r}=$ $0.319)$ and weight $(r=0.205)$ suggests that the lactating women with proportionately higher height and weight had better physical performance.

\section{Materials and Methods}

The study was conducted in Kishanganj and Sahahbad panchayat samities of Baran district (Rajasthan). The random selection method was used in selection of village as well as sample. The list of villages was obtained from tehsil head quarter of Kishanganj and Shahbad. From the list the villages namely Kapri kheda, Bilasgar-I, Bilasgarh-II, Bhanwar garh, Tejaji Ka Danda, Kamdha, Kakarda, Ranibadod-I, Ranibadod-II were selected from Kishanganj and Seemlya, Khushiyara, Mamoni-I, Mamoni-II, Mundiyar, Deori, Shahbad, Kotra, Khushalpura, were selected from Shahbad respectively. The anganwadi centers of each village were visited personally. It consisted of particulars related to the respondents of lactating women i.e. name, age, Anthropometric measurements: - with the determination of weight, height. The values were used to calculate the Body Mass Index (BMI). The obtained values were interpreted as per the classes of BMI given by WHO (2000).

\section{Results and Discussion}

All respondents selected (lactating women 012 months) were lying in the age group of 1845 years. Among them 70\% lactating women (0-6 months) were in the age group of 15-25 year and in similar percentage of women (23.33\% and $26.66 \%$ ) were in age of 26-35 year. The anthropometric indices like mean, height and mean weight of lactating women was $154.03 \mathrm{~cm}$ (0-6 months), $155.18 \mathrm{~cm}$ height (6-12 month) and $49.36 \mathrm{~kg}$ (0-6 month) 
and other $52.08 \mathrm{~kg}$ weight (6-12 month) of lactating women respectively and Distribution of lactating women on the basis of BMI showed that although $66.66 \%$ (0-6 month), $61.66 \%$ (6-12 month) respondents were in normal range but $38.33 \%$ were under weight (Table 1). In a study conducted by Ongosi et al., (2010) of the lactating women (98\%) had a BMI $18.5 \mathrm{~kg} / \mathrm{m}^{2}$, Only two per cent women had a BMI slightly less than $18.5 \mathrm{~kg} / \mathrm{m}^{2}$, i.e. they had $18.4 \mathrm{~kg} / \mathrm{m}^{2}$ and $18.2 \mathrm{~kg} / \mathrm{m}^{2}$ respectively. On the other hand, ten per cent women had a BMI above $27.0 \mathrm{~kg} / \mathrm{m}^{2}$ with the highest BMI being $29.6 \mathrm{~kg} / \mathrm{m}^{2}$, thus giving the study group a mean BMI of $23.9 \mathrm{~kg} / \mathrm{m}^{2}$. The results of the anthropometric indices are in line with study conducted by Mittal (2013), who found that the mean height, weight, BMI and waist hip ratio of the samples were $152 \pm 5.9 \mathrm{~cm}, 49.3 \pm 9.4 \mathrm{~kg}, 21.12 \pm 3.7 \mathrm{~kg} / \mathrm{m}^{2}$ and $0.79 \pm 0.04$ respectively, of the rural women in age group of 18-40 years (Tables 2 and 3 ).

Table.1 Percentage distribution of respondents in view of general information

\begin{tabular}{|c|c|c|c|}
\hline Age & 0-6 Month n=60 & 6-12 Month n=60 & Overall N=120 \\
\hline 15-25 year & $70 \%(42)$ & $66.66 \%(40)$ & $68.33 \%(82)$ \\
\hline 25-35 year & $23.33 \%(14)$ & $26.66 \%(16)$ & $25 \%(30)$ \\
\hline $35-45$ year & $6.66 \%(4)$ & $6.66 \%(4)$ & $6.66 \%(8)$ \\
\hline
\end{tabular}

Table.2 Per cent prevalence of malnutrition among the lactating women $(\mathrm{N}=120)$

\begin{tabular}{|l|l|c|c|}
\hline Anthropometry indices & Type of malnutrition & $\begin{array}{c}\text { 0-6 Month } \\
\text { N=60 }\end{array}$ & $\begin{array}{c}\text { 6-12 month } \\
\text { N=60 }\end{array}$ \\
\hline BMI $\left(\mathbf{k g} / \mathbf{m}^{\mathbf{2}}\right)$ & Underweight & $\mathbf{3 3 . 3 3 \% ( 2 0 )}$ & $\mathbf{3 8 . 3 3 \% ( 2 3 )}$ \\
\hline$<\mathbf{1 8 . 5 0}$ & Severe thinness & $6.6 \%(4)$ & $6.6 \%(4)$ \\
\hline$<16.00$ & Moderate thinness & $6.6 \%(4)$ & $10 \%(6)$ \\
\hline $16.00-16.99$ & Mild thinness & $20 \%(12)$ & $33.33 \%(13)$ \\
\hline $17.00-18.49$ & Normal Range & $\mathbf{6 6 . 6 6 \% ( 4 0 )}$ & $\mathbf{6 1 . 6 6 \% ( 3 7 )}$ \\
\hline $\mathbf{1 8 . 5 0 - 2 4 . 9 9}$ & Overweight & - & - \\
\hline$>\mathbf{2 5 . 0 0}$ & Pre-obese & - & - \\
\hline $25.00-29.99$ & Obese & - & - \\
\hline$>\mathbf{3 0 . 0 0}$ & & & \\
\hline
\end{tabular}

Source: World Health Organization, 2000

Table.3 Mean \pm SD value of anthropometric indices lactating women $(\mathrm{N}=120)$

\begin{tabular}{|l|c|c|}
\hline & 0-6 Month N=60 & 6-12 Month $\mathbf{N = 6 0}$ \\
\hline Anthropometry indices & Mean \pm SD & Mean \pm SD \\
\hline Height $(\mathbf{c m})$ & $154.03 \pm 2.67$ & $155.18 \pm 3.93$ \\
\hline Weight $(\mathbf{k g})$ & $49.36 \pm 2.19$ & $52.08 \pm 3.00$ \\
\hline BMI $\left(\mathbf{k g} / \mathbf{m}^{2}\right)$ & $20.77 \pm 0.88$ & $21.63 \pm 0.68$ \\
\hline
\end{tabular}

It can be concluded that the nutritional knowledge of the participant was very low. Food consumed by the lactating women was inadequate in most of the food groups when compared with balance diet and inclusion of protein and fruit was low. Anthropometric 
measurement showed that majority of the lactating women were underweight.

\section{References}

Bakhetia, P., and Jain, R. 2007. Anthropometric profile and physical performance of rural school girls. Anthropologist, 9: 139-410.

Kapoor, S., Renu Tyagi1, Kiran Saluja, Anumeha Chaturvedi and A.K. Kapoor. 2009. Nutritional Profile and SocioEconomic Status of Shariya, a Primitive tribe of India. The Open Anthropology Journal, 2, (58-63).

Mittal, M., 2013. To assess the nutritional status and morbidity patterns among non-pregnant non-lactating rural women of reproductive age group (18-40 Years). International Journal of Scientific and Research Publications, 3.

Ongosi, A.N., 2010. Nutrient intake and nutrition knowledge of lactating women (0-6 months postpartum) in a Low Socio-Economic Area in Nairobi, Kenya, University of Pretoria.

Rao, K.M., Kumar, R.H., Venkaiah, K. and Brahman, G.N.V. 2006. Nutritional status of Saharia - A Primitive Tribe of Rajasthan. Journal Human Ecology, 19(2): 117-123.

Wagstaff, A., 2000. Poverty and health sector inequalities. Bulletin WHO. 80(2): 97105.

\section{How to cite this article:}

Tanuja Bairwa, Seema Jat, Kavita Bairwa and Devi Sahay Bairwa. 2017. A Study of Anthropometry Measurement of Shariya Tribe Lactating Women in Baran District of Rajasthan, India. Int.J.Curr.Microbiol.App.Sci. 6(9): 607-610. doi: https://doi.org/10.20546/ijcmas.2017.609.074 